\title{
LA INMACULADA Y MIGUEL CID, DE PACHECO *
}

RAFAel Cómez

A medida que avanzan los estudios de historia social y económica de] siglo xvIr en España, se hace más urgente para la historia de las mentalidades el conocimiento de las implicaciones sociales y religiosas de los temas iconográficos contrarreformistas que, a través de la pintura, se extenderían por todo el mundo hispánico. ${ }^{1}$ En este sentido, la época del reinado de Felipe III, es decir, el primer cuarto del siglo xvir, se nos presenta como una etapa de peculiar efervescencia religiosa en que se entablará, tras ruidosas campañas oficiales y demostraciones populares, una apasionada disputa sobre el dogma de la Inmaculada Concepción de María que tuvo un feliz exponente en las manifestaciones de las artes plásticas de la escuela sevillana.

El análisis de la Inmaculada y Miguel Cid, obra de Francisco Pacheco, el pintor y tratadista más influyente de aquel momento, amigo y colaborador del escultor Martínez Montañés, y además maestro de Alfonso Cano y de Velázquez, nos permitixá investigar: 1ㅇ, los orígenes de las formas complejas de ciertas manifestaciones de la vida religiosa sevillana y los medios utilizados por la Iglesia para el mantenimiento y pervivencia de un tema iconográfico que consideraba conveniente para el adoctrinamiento de sus fieles; $2^{\circ}$, el procedimiento mediante el cual el Concilio de Trento se mantuvo fiel a la doctrina tradicional

* El tema del presente artículo fue ideado en la Universidad de Sevilla, discutido con el profesor Jonathan Brown en la Universidad de Princeton y finalmente redactado en México. El autor, al igual que el padre Lepicier en su obra sobre la Inmaculada Concepción, desea de entrada hacer expresa declaración de que "para conformarse enteramente a las prescripciones de la Santa Iglesia, en particular a los decretos de Urbano VIII, no entiende conceder tanto a los hechos aportados como a las expresiones empleadas en esta obra más que un valor histórico y pura mente humano".

1 En este sentido resulta ejemplar la obra de V. L. Tapié, Retables baroques de Bretagne et spiritualité du xvIr siècle. Etude semiographique et religieuse, Paris. 1972. Sobre el tema de la Inmaculada en España sólo hemos hallado el viejo estudio de E. Tormo, "La Inmaculada y el arte español", Boletin de la Sociedad Española de Excursiones, XXII, Madrid, 1914, pp. 108.218, que se trató de un curso de conferencias organizado por la "Junta de Damas Españolas del Sagrado Corazón, Federación Nacional de Obras Católico-Femeninas" para lograr fondos para su "Sección de Socorro y de Protección al Trabajo de la Mujer", bajo la presidencia del señor obispo de Madrid en el salón del Hotel Ritz. 
precisándola y depurándola, al tiempo que con sus enseñanzas sobre la hiperdulía resucitaba el culto a la Virgen, denostado por los protestantes y que tanta piedad había suscitado en la Edad Media; 3!, la imagen como algo "instituido", que se conserva y actúa en el tiempo; en otras palabras, el proceso por el cual lo histórico se transforma en estético.

El primer cuarto del siglo xvir en España supone una época de gran efervescencia religiosa que, estéticamente, coincide con el advenimiento del tenebrismo pictórico de Caravaggio. Felipe III, que había expul. sado a los moriscos en 1609, con consecuencias funestas para la economía española, se había convertido en el adalid de la religiosidad hispana. Junto con la reina Margarita había fundado hasta catorce con. ventos. El cardenal Juan de Ribera fundaba el Colegio del Patriarca, en Valencia. En Sevilla, se edificaba la Iglesia de los Jesuitas y el Convento de la Merced. Se celebraban con grandes fiestas la "promoción" de los santos españoles canonizados entre 1618 y 1622: Santo Tomás de Villanueva, Santa Teresa de Jesús, San Ignacio de Loyola, San Francisco Javier y San Isidro Labrador, patrón de Madrid. A todo ello se une la clamorosa campaña para conseguir que Roma reconozca el dogma de la Inmaculada Concepción de Marła, que fue también apoyada y favorecida personalmente por el rey Felipe III.

Hay que preguntarse por las causas de las estrepitosas manifestaciones en pro del dogma de la Inmaculada Concepción de María en Sevilla que Domínguez Ortiz ha calificado de auténtica "explosión concepcionista".2 Desgraciadamente, carecemos de estudios que analicen los orígenes de este interesante fenómeno, y, en general, se atribuye a la tradicional devoción mariana o a la acendrada piedad del pueblo sevillano. ${ }^{3}$ En realidad, éstos no son más que argumentos ro mánticos que ya enunciaron los viajeros ingleses del siglo xix.. ${ }^{4} \mathrm{El}$ se.-

2 A. Domínguez Ontiz y F. Aguilar Piñal, Historia de Sevilla IV: el Barroco y la Ilustración, Sevilla, 1976, p. 107.

3 M. Serrano Ortega, Glorias sevillanas. Noticia histórica de la devoción y culto que la Muy Noble y Muy Leal Ciudad de Sevilla ha profesado a la Inmaculada Concepción, Sevilla, 1893; A. Domínguez Ortiz, op. cit, p. 107.

4 Richard Ford, Manual para viajeros por Andalucia y lectores en casa, Madrid, 1980, p. 11; "Eminentemente supersticiosos, la Mariolatría ha sucedido aquí a la 
villano Blanco White, desde su exilio voluntario en Londres, fue el primero en exponer con rigor crítico la historia de la famosa disputa sevillana por el dogma concepcionista, pero, desde entonces, no conocemos quien haya tratado el tema desapasionadamente. ${ }^{5}$

Las disputas teológicas sobre la Inmaculada Concepción de la Virgen eran ya antiguas en el siglo xvir y en ellas se habían debatido franciscanos y dominicos desde el siglo xIIr, pero en Sevilla adquirieron especial virulencia a partir de un hecho que Ortiz de Zúñiga nos cuenta puntualmente en sus Anales: en 1613, en un sexmón que se predicaba en la Catedral de Sevilla, un dominico se atrevió a expresar ciertas dudas acerca de la Inmaculada Concepción, lo cual tomado como una ofensa no sólo contra la Virgen María sino contra toda la ciudad de Sevilla, provocando la ira del pueblo que intentó agredir al predicador. ${ }^{\dot{6}}$

Este hecho no fue más que el inicio de una serie de manifestaciones populares en las que los dominicos saldrían abucheados y malparados. Ciertamente, los dominicos habían llevado al límite de discusión bizantina detalles no esenciales de la no muy clara doctrina de Santo Tomás respecto a la Inmaculada Concepción de María. Sin embargo, no resulta menos cierto que franciscanos y jesuitas vieron en este incidente la mejor ocasión para subyugar la soberbia de los dominicos. Añádase que el prior del convento dominico de Regina publicó unas conclusiones en contra del dogma de la Inmaculada, y tendremos ya planteado el conflicto que va a provocar incluso alteraciones de orden público.

Se generalizó el uso de la invocación "Ave María Purísima" que los dominicos siempre se negaron a pronunciar el comienzo de sus sermones. Y cuando la disputa alcanzaba su clímax, el pueblo sevillano tomó la costumbre de reunirse en las iglesias y salir en procesión presidida por un estandarte en el que figuraba pintada la imagen de la Virgen Inmaculada, los cuales estandartes siguen usándose en la actualidad bajo el nombre de "simpecados" ${ }^{7}$ La gente cantaba por las calles

adoración de la Salambó bética, la Venus y la Astarté de los fenicios; esto y una confianza en la ayuda sobrenatural y el capitulo de lo fortuito, he aqui el recurso más corriente en todas las circunstancias de dificultad".

5 J. Blanco White, Cartas de España, $2^{\text {a }}$ ed, Madrid 1977, p. 52.

6 D. Ortiz de Zúñiga, Anales, IV, 2a ed, Madxid, 1796, pp. 234.242.

$7 \mathrm{~J}$. Blanco White, op. cit., p. 52. 
las coplas compuestas por Miguel Cid con música del padre Bernardo del Toro, defendiendo el dogma concepcionista, cuyo estribillo decía:

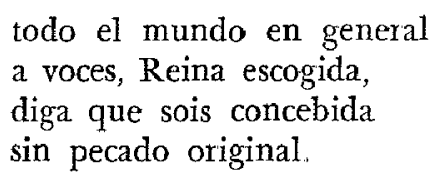

Blanco White afirma que fue el arzobispo Vaca de Castro quien encargó la composición de estas coplas, ${ }^{8}$ mientras que Tormo atribuye el encargo al arcediano Vázquez de Leca ${ }^{\circ}$ Quienquiera que haya sido el mecenas conocía la eficacia de los recursos musicales como propaganda popular, ya que dichas letras se siguen cantando hasta nuestros días. Tanto uno como otro estaban interesados en la campaña, y sabemos, con toda certeza, que el arcediano Vázquez de Leca no ignoraba tampoco la drasticidad de los recursos visuales de las artes plásticas. Cliente de Martínez Montañés, a quien había encargado el famoso Cristo crucificado de la Sacristía de los Cálices de la Catedral de Sevilla, ${ }^{10}$ Vázquez de Leca fue retratado también por Pacheco, en 1621, a los pies de la Inmaculada en un lienzo hoy propiedad de la Marquesa de la Reunión de Nueva España, en su hacienda de Castilleja de la Cuesta.11

Pero continuemos con el desarrollo de los hechos. Los dominicos que no podían admitir la ola de denuestos desatada contra ellos acudieron a Madrid y a Roma. Sin embargo, un informe presentado por el arzobispo Vaca de Castro revela el clima de irracionalidad y alucinamiento colectivo que vivía la ciudad de Sevilla, al propio tiempo que manifiesta la total parcialidad del arzobispo en el asunto, ya que convierte la polémica en una historia de buenos y malos en la que todo lo que hace el pueblo es positivo y a los dominicos les toca la peor parte. ${ }^{12} \mathrm{Y}$ aquí es donde vemos el papel distorsionador que tuvo

8 J. Blanco White, op. cit., p. 335 .

9 E. Tormo, op. cit., p 189. Las coplas se imprimieron en 1615,

$10 \mathrm{~J}$. Hernández Díaz, Martinez Montañés, Sevilla, 1976. El contrato estipulaba "que ha de estar vivo, antes de haber expirado, con la cabeza inclinada sobre el lado derecho, mirando a cualquier persona que esturiera orando al pie de él, como que está el mismo Cristo hablándole y como quejándose que aquello que padece es por él..."

11 J. Hernández Díaz, A. Sancho Corbacho y F. Collantes de Terán, Catálogo Arqueológico y Artistico de la Provincia de Sevilla, II, Sevilla, 1943, p. 300.

12 "Comenzaron a salir de noche cantando coplas Prohibióseles salir de noche. 
el arzobispo Vaca de Castro. El ilustre prelado, que había dejado la Silla de Granada por la de Sevilla, acérrimo defensor del dogma de la Inmaculada basándose en la autoridad de los Libros Plúmbeos de Sacro Monte, había fundado en Granada la Colegiata de Sacro Monte donde se habían hallado los famosos Libros Plúmbeos, cuyos textos probaban la antigüedad del dogma de la Inmaculada Concepción en España, en el cual creía ya el mismísimo Santiago Apóstol, evangelizador de la Patria. Los libros Plúmbeos fueron llevados a Roma en 1641, condenados en 1682 e incluidos en el Indice expurgatorio.13 Así pues, a la soberbia del ilustre prelado y no a la de los dominicos debemos atribuir las causas del conflicto. Vaca de Castro, venido de la diócesis de Granada, donde había vivido el entusiasmo popular por el hallazgo de los Libros Plúmbeos, probablemente proyectó en Sevilla una campaña similar a la granadina, en la que el incidente del sermón del dominico en la Catedral de Sevilla en 1613 fue meramente la chispa que inició la "explosión concepcionista".

Mientras, en Roma, se debatía por la definición del dogma, en el que incluso el monarca Felipe III había puesto todo su empeño. No se consiguió pero se concedió absoluta libentad para que se continuara aquella "opinión pía". Tan sólo este permiso significó oleadas de entusiasmo en el pueblo sevillano. Al llegar la bula papal a Sevilla en octubre de 1617, se organizaron corridas de toros, juegos de cañas y un torneo alegórico, costeado por el gremio de sederos, enriquecidos entonces por el monopolio con las colonias americanas. Amén de estos festejos la cofradía de Jesús Nazareno, que había hecho votos de defender hasta la última gota de su sangre la Purísima Concepción de María, organizó una magna procesión que, saliendo de su iglesia, cantó por las calles el himno de la Inmaculada. A medianoche las campanas de la Catedral y de todos los conventos e iglesias de Sevilla se soltaron al vuelo, mientras que miles de luminarias y fuegos artificiales resplan. decían en la ciudad. ${ }^{14}$ Éste diríamos que fue el aspecto externo, ya que,

Juntóse gran multitud de gentes cantándolas por las calles con mucha música sin ofensa de nadie. $Y$ han hecho algunas con gran acoūpañăāuiento de la nobleza eclesiástica y secular e innumerables pueblos, tanto que no se cree si no se ve. Con la misma devoción han puesto por la ciudad rótulos que dicen; María sin pecado original. Casi no hay lugar donde no esté puesto" (28 de julio de 1615) Apud A. Domínguez Ortiz, op. cit., p 108.

13 E. Tormo, op. cit., p. 182

14 A Domínguez Ortiz, op. cit, p. 108; J. Blanco White, op cit., pp, 336-337. 
por otro lado, las corporaciones oficiales establecían para ingresar en ellas el juramento previo de defender el dogma concepcionista, costumbre que podemos rastrear hasta hoy dia en la Academia de Bellas Artes y en la Universidad Hispalense.

La Iglesia española era muy rica en este momento. Los ingresos de los capitulares de la Catedral de Sevilla habían aumentado considerablemente, y del siglo xvi al xvIr el valor de sus canongías había subido nada menos de 300 a 2000 ducados. Crecía el poder de las órdenes religiosas y se creaban otras nuevas a las que accedían individuos presionados más por la necesidad de subsistencia que por una auténtica vocación. Sólo de franciscanos y dominicos se cita la cifra de $32000 .{ }^{15}$ Como afirma Domínguez Ortiz, la Iglesia española, a pesar de sus defectos, disfrutaba de una gran popularidad porque de alguna manera cumplia atribuciones que se han transferido hoy al Estado..16 Conocedora de su poder y apoyándose en la profunda fe de las masas podía concertar grandes movimientos populares como el que acabamos de describir, valiéndose del indiscutible valor de la palabra, la música y las artes visuales. En suma, estamos contemplando el dinámico proceso de formación de lo que Maravall denomina caracteres sociales de la cultura del barroco, que la constituyen como una cultura dirigida, masiva, urbana y conservadora. ${ }^{17}$

Parte importante de este proceso de formación va a ser la creación de temas, de modelos, de tipos iconográficos que tendrán una larga vida. Tal la Inmaculada Concepción. Sabemos que en pocos años Francisco Pacheco pintó seis lienzos con el tema de la Inmaculada Concepción, de los cuales, tres pintados en 1621 ostentan el retrato de un personaje a sus pies a manera de los donantes medievales. Ellos son: a) el del doctor Jerónimo Herrera que poseía en Sevilla don Juan

También en México se celebró con fiestas y procesiones la Inmaculada Concepción de Maria como nos refiere G. M. de Guijo, Diario (1648.1664), ed. de M. Romero de Terreros, México, 1952, II, pp. $206-209$ y ss.: "La real Universidad de esta cancillería movida a instancia del Dr. don Pedro de Gálvez, visitador de este reino, juntó a claustro pleno de sus doctores, y asentó celebrar perpetuamente la singular festividad de la Concepción de la Serenísima Reina de los Angeles en su capilla a imitación de todas las Universidades de los reinos de Castilla que la celebran..." (i8 enero, 1653).

15 J. H. Elliott, La España Imperial (1469-1716), Barcelona, 1978, p. 339.

16 A. Domínguez Ortiz, op. cit, p. 103.

$17 \mathrm{~J}$. A. Maravall, La cultura del barroco. Análisis de una estructura histórica, Barcelona, 1975, p. 129 
Olivar; $b$ ) el del arcediano Vázquez de Leca, propiedad de la Marquesa de la Reunión de Nueva España en Castilleja de la Cuesta, ya mencionado; c) el del poeta Miguel Cid, en la Sacristía de los Cálices de la Catedral de Sevilla, objeto de nuestro estudio. ${ }^{18}$

Esto significa que en 1621, un año después de que Pacheco firmara la dedicatoria de su folleto titulado Apacible conversación entre un tomista y un congregado, acerca del misterio de la Purisima Concepción, ${ }^{19}$ y cuatro años después del estrepitoso recibimiento de la bula papal de 1617, se iniciaba una segunda fase de la campaña, ahora más apaciguada y sutil, encabezada por Pacheco que había sido nombrado en 1618, Censor y Visitador de pinturas sagradas por la Inquisición, ${ }^{20}$ en la que por medio de "apacible" diálogo y persuasivas representaciones plásticas del dogma concepcionista se consiguiera convencer a los reticentes y crear un clima espiritual favorable para la aprobación y definición del dogma por parte de Roma ya que la anterior petición, patrocinada personalmente por Felipe III -que fallecía en este año de 1621-, no había obtenido los frutos deseados. También va a ser durante esta segunda fase cuando su amigo, el imaginero Martínez Montañés realice algunas de las mejores expresiones escultóricas del dogma. ${ }^{21}$

Tan sólo se consiguió de Roma, ya en 1661, la bula que autorizaba la celebración de una fiesta especial dedicada a la Purísima Concepción de María. ${ }^{22}$ Más tarde, en 1682, se condenaban e incluían en e1 Indice los llamados Libros Plúmbeos, donde se probaba, según el arzobispo Vaca de Castro, la antigüedad del dogma concepcionista en España, como hemos dicho anteriormente. Finalmente, durante el reinado de Carlos III, bajo presiones del gobierno español, el Papado

18 F. Pacheco. Arte de la Pintura, ed. de F. J. Sánchez Cantón, Madrid, MCMLVI, pp. XLIII, xLIV y xLV. Las otras tres Inmaculadas sin donantes son: a) la de la Parroquia de San Loxenzo de Sevilla; b) la de la colección Lastra de Madrid; c) la de la capilla de la Universidad de Navarra en Pamplona. El cuadro de la Inmaculada y Miguel Cid de la Sacristía de los Cálices de la Catedral de Sevilla mide 1.50 metros de alto por 1.10 de ancho.

19 Lo publicó J. M. Asensio, Pacheco y sus obras artisticas y literarias, Sevilla, 1886, pp. 268-294. Para la cronología vid. F. Pacheco, op. cit, p. XIIII

20 F. Pacheco, op. cit., p. XLII.

21 J Hernández Díaz, op. cit, passim.

22 A Domínguez Ortiz, op. cit, p. 109. 
accedería a una solución de compromiso sin incluir la Inmaculada Concepción de María dentro de los dogmas de la Iglesia Católica. ${ }^{23}$

Para entonces el tipo iconográfico iniciado por Pacheco había obtenido suficiente éxito Ello nos muestra el poder de la Iglesia española de aquel momento. La serie de personajes retratados a los pies de la Inmaculada por Pacheco en el mismo año de 1621 evidencia doblemente los fuertes lazos que unían a la aristocracia sevillana con la Iglesia y, por otro Iado, el claro deseo de perpetuarse junto al "dogma", de "eternizarse", sirviendo de ejemplo a las generaciones venideras.

Por un manuscrito de la Biblioteca Colombina, sabemos que en 1687 permanecía el cuadro de Miguel Cid y la Inmaculada en la nave del Lagarto, a la puerta de la Catedral de Sevilla, frente a la capilla de la Granada, junto al púlpito que servía para predicar el sermón todos los domingos del año.24

¿Quién era Miguel Cidd? Miguel Cid "que al coro de las Musas pone espanto", como dijera Cervantes, era un poeta mediano, un versificador sin estudios ni letras, según sostienen sus biógrafos ${ }^{25}$ cuya fama se debió a aquellas coplas que les encargara el arcediano Vázquez de Leca que rápidamente se hicieron populares.

Ufano del papel que le ha tocado representar en la contienda, aparece retratado a los pies, de la Virgen mostrando sus coplas en la mano derecha. Situado en el ángulo inferior derecho del lienzo -izquierdo del espectador - se encuentra respaldado por las dos famosas torres de Sevilla, la Giralda y la Torre del Oro, guardiana de los tesoros llegados de América, que forman parte de un paisaje naturalista en el que una carabela se acerca al puerto. En el ángulo inferior izquierdo se destacan los símbolos de la letanía.

La imagen de la Inmaculada aparece hierática, falta de movimiento, pisando la luna, "en la flor de su edad, de doce a trece años, hermo-

23 J. Blanco White, op. cit, p. 53 .

24 Juan Ignacio de Góngora, Memorias de diferentes cosas sucedidas en esta ciudad de Sevilla recogidas en 1689 por $D$, Diego Ignacio de Góngora, mm.ss. que al parecer escribió el $24 \mathrm{D}$. Pedro de Rojas, (Biblioteca Colombina) apud J Gestoso, Sevilla monumental y artistica, II, Sevilla, 1886, p. 492.

25 J. M. Asensio, op cit, p. 23; S. Vranich, "Miguel Cid (c. 1550-1615) un bos. quejo biográfico", Archivo Hispalense, LXV, 1973, pp. 185-207. 
sísima niña, lindos y graves ojos, nariz y boca perfectísima y rosadas mejillas, los bellísimos cabellos tendidos", como quería Pacheco en su Arte de la Pintura, ${ }^{26}$ "vestida de sol, un sol ovado de ocre y blanco, que cerque toda la imagen, unido dulcemente con el cielo; coronada de estrellas, doce estrellas compartidas en un círculo claro entre res. plandores, sirviendo de punto la sagrada frente".

Si es cierta la influencia de Velázquez que Priscilla Muller pretende ver en este lienzo, ${ }^{27}$ habría que limitarla, tal vez, al paisaje de fondo y al retrato del personaje donde parece advertirse la peculiar pincelada del yerno de Pacheco. Por otra parte, Velázquez que no marchó a Madrid hasta 1623 y destacaba ya en Sevilla como buen pintor, pudo muy bien ayudar a su suegro en 1621, cuando recibió los encargos de las tres Inmaculadas con donantes.

En alguna ocasión se ha señalado el carácter narrativo y medieval de los conjuntos urbanos en los fondos de la pintura barroca sevillana. ${ }^{28}$ En este sentido, Pacheco no es excepción, y en esta Inmaculada de Miguel Cid no sólo por el fondo paisajístico sino también por la composición, podriamos ver una trasposición del tema medieval de la Virgen con el donante. Una persistencia de dicho tema pero, en ningún modo, un arcaísmo vigente sino una transformación moderna de] modelo original medieval que se adapta inmejorablemente a la nueva circunstancia social y religiosa. Pacheco es un hombre moderno en las ideas, innovador en el arte, pero reaccionario.

El paisaje es naturalista, es la ciudad de Dios pero también la ciudad de los hombres, en la que podemos identificar la Giralda y la Torre del Oro. Se han concretizado las abstracciones medievales pero el espíritu medieval yace subterráneo. $\mathrm{Y}$ la composición con el donante es netamente medieval. No faltaban en Sevilla representaciones pictóricas de la Virgen con el donante, y las de Alejo Fernández eran un ejemplo bien visible.

Téngase en cuenta que a Pacheco se le presentaba el reto de crear un tipo artístico de María, no como madre con el niño sino aislada, simbolizando una idea abstracta, un dogma teológico que aún no ha.

26 F. Pacheco, op. cit., II, lib. 3, cap. xI, p. 208.

27 P. Muller. "Francisco Pacheco as a Painter", Marsyas, 19, 1961, pp. 39-44;

J. Gallego, Velázquez en Sevilia, Sevilla, 1975.

28 Aurora León, "La arquitectura en la pintura barroca sevillana", Actas del XXIII Congreso Internacional de Historia del Arte, Granada, 1973, III, p. 127. 
bía sido aprobado por la Iglesia. Y ello en un momento en que el estilo imperante era abiertamente naturalista. Al describir este lienzo, Angulo usa la expresión exacta cuando dice que los símbolos de la letanía "se funden" con el paisaje naturalista. ${ }^{29}$ Es decir, se concretizan las abstracciones medievales, como decíamos antes, fusionándose con el naturalismo del paisaje; se imbrica lo concreto y lo abstracto en admirable síntesis. Y como haya dicho Jacques Le Goff: "La imbricación de lo concreto y de lo abstracto es el fondo mismo de la estructura de las mentalidades y de las sensibilidades medievales". ${ }^{30}$

$Y$ es éste un aspecto a veces olvidado dentro de los caracteres de la cultura del barroco: las supervivencias medievales. Muchas ideas y direcciones de la Edad Media persisten en la Europa de los siglos xvi y xvin. ${ }^{81}$ En el orden político no es otro el fondo de la teoría del origen divino del poder. España supo cultivar estas supervivencias fecundándolas con el pensamiento renacentista, como afirmara Menéndez Pi. dal, ${ }^{32}$ y símbolo de este proceso es el Quijote, la última de las novelas de caballería.

En el Hortus Delitiarum de Herrade de Landsberg aparece ya la mujer vestida de sol pisando la luna. ${ }^{33}$ No faltan representaciones de la Inmaculada en la Edad Media y la que pintó Giovanni del Biondo -hoy en la Galería Vaticana- representa un interesante ejemplo. Sin embargo, no hallamos ningún precedente iconográfico a la Inmaculada de Pacheco en toda la producción concepcionista española y europea durante la Edad Media y el Renacimiento. ${ }^{34}$

Si nos detenemos a analizar la Inmaculada de Juan de Juanes de la

29 D. Angulo, Pintura del siglo xvir, "Ars Hispaniae", xv, p. 323.

$30 \mathrm{~J}$. Le Goff, La civilisation de l'Occident médieval, p. 411 apud V. L. Tapié, op. cit., p. 9 .

31 L. Thorndike, "The Survival of Mediaeval Intellectual Interest into Early Modern Times", Speculum 1927, pp. 147-159. Sobre las supervivencias medievales en el arte barroco vid. $\mathrm{E}$. Mâle, El arte religioso del siglo XII al siglo XVII, México. 1966, p. 181; G. Bazin, The Baroque, Greenwich, 1968, p. 78; y V. L. Tapié, op cit., $\mathrm{pp} 8$ y 36 .

32 R. Menéndez Pidal, La España del Cid, II, Madrid, 1969, p. 659.

$33 \mathbf{H}$. de Landsberg, Hortus Delitianum, ed. de $\mathbf{R}$. Green, The Warburg Insti. tute, London, I, p. 323.

$34 \mathrm{E}$. Tormo, op, cit.; M. Trens, Maria. Iconografia de la Virgen en el arte español, Madrid, 1947; A. M. Lepicier, L'Inmaculée Conception dans l'Art et l'Ico. nographie, Spa 1956; M Levi D'Ancona, The Iconography of the Inmaculate Con. ception in the Middle Ages and Early Renaissance, New York, 195\%; y E. Mâle, op cit, p. 161-162. 
Iglesia de la Compañía de Valencia, veremos que alli la Virgen es coronada por el Padre y el Hijo, presididos por el Espíritu Santo. En la Inmaculada y el Padre Mata de Juan de las Roelas, la Virgen pisa la media luna y es coronada por dos ángeles. ${ }^{35}$ En cambio, la Inmaculada y Miguel Cid de Pacheco es diferente; aquí la Virgen aparece ya coronada y pisando una luna translúcida.

Parece ser que el tipo iconográfico de la Inmaculada de Juan de Juanes, es decir, la Virgen vestida de túnica blanca y manto azul, pisando la luna mientras el Padre y el Hijo la coronan, se atribuye a sor Isabel de Villena, abadesa del Real Convento de Franciscanas de la Trinidad en Valencia. Esta monja era hija del famoso escritor Enrique de Villena y estuvo encargada de la educación de una de las hijas bastardas de Fernando el Católico. Asimismo, autora del libro Vita Christi publicado por deseos de la reiná Isabel la Católica en 1497 y reimpreso en años sucesivos. ${ }^{36}$

Pacheco en su Arte de la Pintura considera que la Inmaculada se ha de pintar con túnica blanca y manto azul como se le apareció a doña Beatriz de Silva, que fundó en Santo Domingo el Real de Toledo la religión de la Concepción Purisima, confirmada por el Papa Julio II en $1511 .^{37}$ Así pues, las fuentes de inspiración de Juan de Juanes y de Pacheco son diferentes aunque ambas Inmaculadas coinciden en estar vestidas de blanco y azul y en aparecerse en Reales Conventos.

Las dos apariciones o visiones nos hablan de cierto fervor concepcionista hispano a fines de la Edad Media que, más tarde, se verá confirmado oficialmente por el Papado y por los Reyes Católicos. Curiosamente, las apariciones tienen lugar en dos importantes capitales, Toledo y Valencia, de los dos reinos que han forjado la unidad penin. sular, y precisamente en Reales Conventos.

Aunque algunos obispos españoles del siglo xvil expresaban su hostilidad a la pintura, como sinónimo de engaño, 38 el Concilio de Trento en su sesión xxv, al tratar "De la invocación, veneración y reliquias

35 D. Angulo, Pintura del Renacimiento, "Ars Hispaniae", Xī, pp. 319 y 327 ; vid, también J. Albi, Joan de Joanes y su circulo artístico, Valencia, 1979, y E Valdivieso, Juan de las Roelas, Sevilla, 1978.

$36 \mathrm{E}$. Tormo, op. cit, $\mathrm{p} 120$

37 F. Pacheco, op. cit, p. 211.

$38 \mathrm{~J}$. Caro Baroja, Las formas complejas de la vida religiosa. Religión, sociedad y caracter de la España de los siglos xvi y xvII, Madrid, 1978, p. 108. 
de los santos y sagradas imágenes" las recomendaba a los obispos por el mucho fruto que se saca de ellas. ${ }^{39}$ Del mismo modo que la Con. trarreforma no había inventado el retablo, que era una creación medieval, así también retomó las viejas creencias medievales precisándolas y depurándolas con objeto de adaptarlas a las nuevas circunstancias históricas, como ha expuesto claramente Tapié. ${ }^{40}$ Entre estas viejas creencias se encuentra la de la Inmaculada Concepción que no se convertiría en dogma hasta dos siglos después. Otras creencias, como la del unicornio como símbolo de la Encarnación desaparecerían ante la ironía de la crítica protestante.41 Que el formalista Pacheco no ignoraba este aspecto conservador de la Contrarreforma lo prueba su utilización de la tipología del Cristo crucificado con cuatro clavos, el mismo tipo del crucificado románico, que defiende en su Arte de la pintura, basándose en la visión de Santa Brígida.

\section{III}

Pacheco es el gozne que engarza el manierismo hispano con el barroco. En este sentido su pintura participa de los caracteres de un arte elitista como es el manierismo y de los caracteres de un arte de gran

39 El sacrosanto y ecuménico concilio de Trento, traducido al idioma castellano por don Ignacio López de Ayala... Segunda edición. Con privilegio. En Madrid. en la Imprenta Real, 1785, p. 477: "Enseñen con esmero los obispos que por medio de las historias de nuestra Redención, expresadas en pinturas y otras copias, se instruye y confirma el pueblo, recordándole los artículos de la fe y recapacitándole continuamente en ellos; además que se saca mucho fruto de todas las sagradas imágenes por los beneficios $\mathrm{y}$ dones que Cristo les ha concedido, sino también porque se exponen a los ojos de los fieles los saludables ejemplos de los santos y los milagros que Dios ha obrado por ellos" (Sesión XXV ... 3, 4.X-1563). Estas son las directrices de Juan de Ávila cuando, al recomendarle a un prelado de Granada las imágenes necesarias para adocttinar a las pobres gentes de los pueblos de la diócesis, dice: "Y los pueblos han menester todas estas salsas para comer su manjar: rosanios, imágenes han de ser muchas; y los ricos cómprentos de las ciudades" (Epistolario espiritual, X, "Biblioteca de Autores Españoles", XIII, p. 297 b.). Sobre la teoría teológica del arte en la literatura española del siglo xvir vid

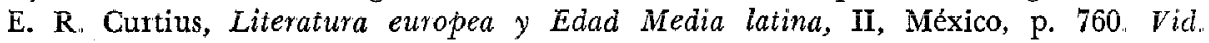
también el interesante artículo de J. Yarza, "Aspectos iconográficos de la pintura de Juan Fernández Navarrete El Mudo y relaciones con la Contrarteforma", Boletin del Seminario de Estudios de Arte y Arqueologia "Universidad de Valladolid, XXXVI, 1970, pp $43-68$

40 V. L Tapié, op. cit., $\mathrm{pp}^{8}$ 8-18.

41 L. Réau, Iconographie de l'art chrétien, I, París, 1955, p. 91. 
DOI: http://dx.doi.org/10.22201/iie.18703062e.1983.52.1189

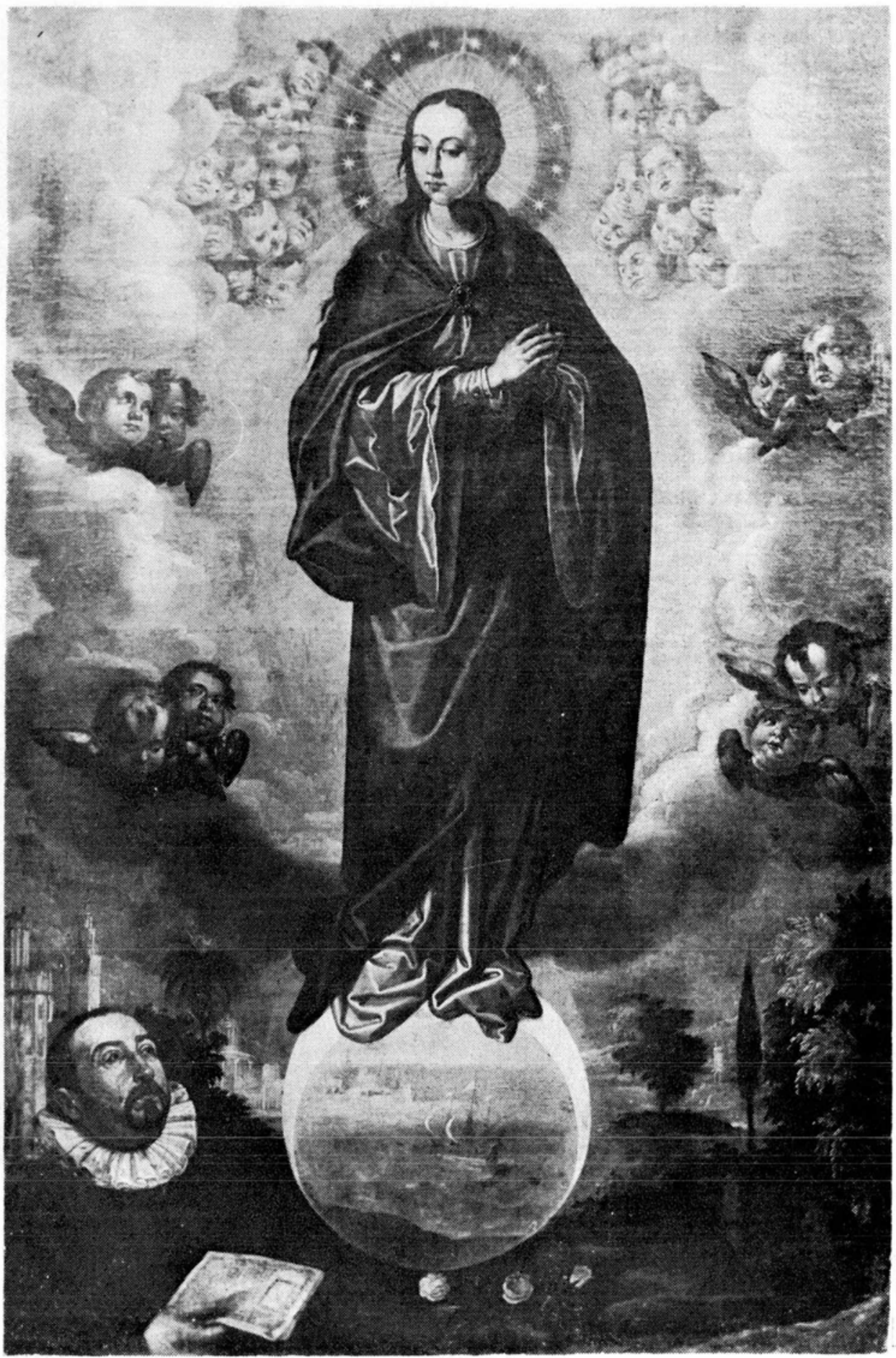

Figura 1. La Inmaculada Concepción y Miguel Cid. Foto Laboratorio de Arte. Universidal de Sevilla. 
DOI: http://dx.doi.org/10.22201/iie.18703062e.1983.52.1189

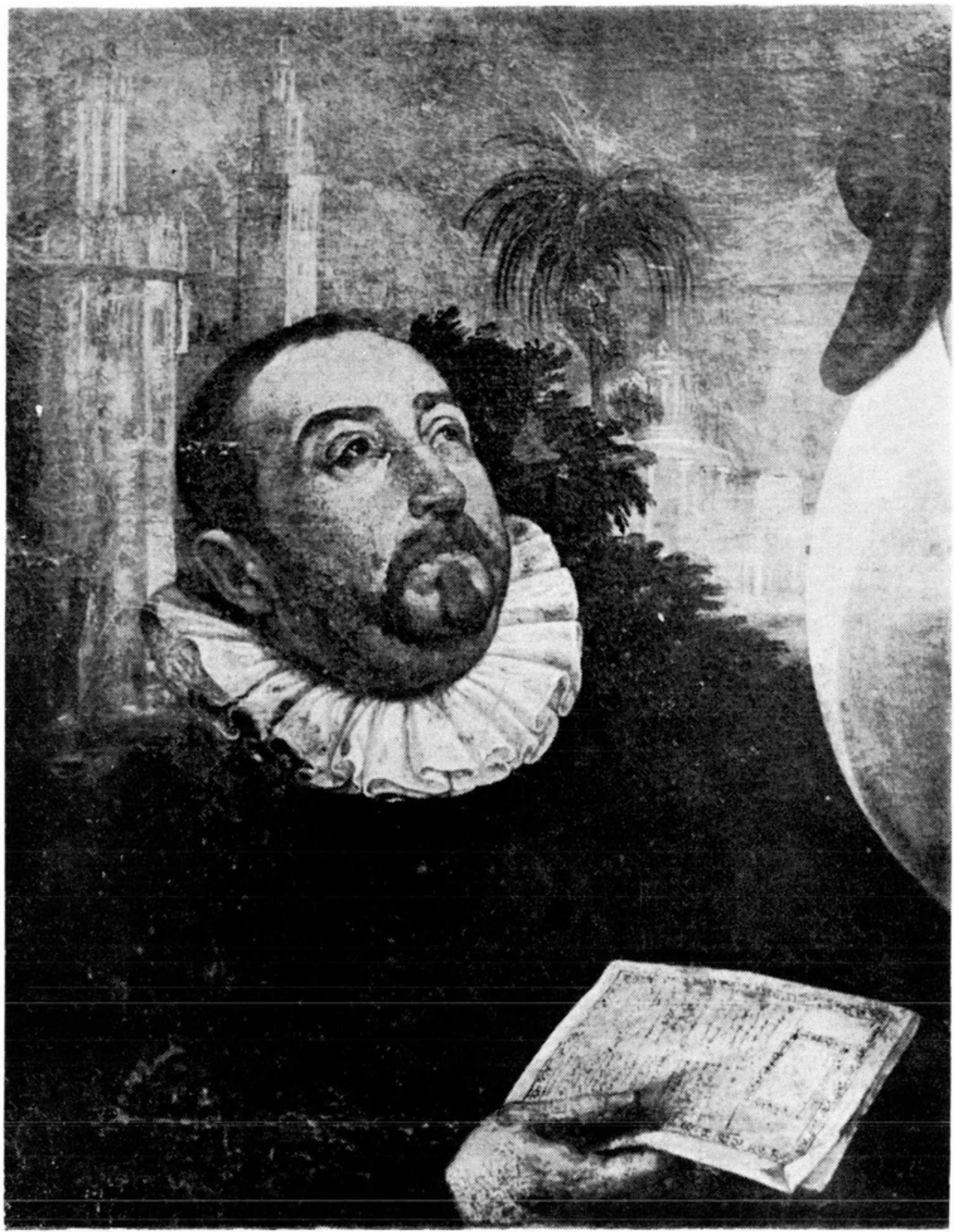

Figura 2. Miguel Cid. Foto Laboratorio de Arte. Universidad de Sevilla. 
audiencia popular como es el barroco. La supresión de la élite eras. mista del siglo xvI y la aparición del grupo integrista y reaccionario de la tertulia de Pacheco había sumido a las minorías hispalenses en una grata tranquilidad de conciencia. ${ }^{42}$

El ilustre tratadista de arte, "el más representativo y oficial de los pintores andaluces de la primera generación del Siglo de Oro" como le llama Gállego, ${ }^{43}$ era la persona más indicada para codificar lo que en adelante sería la "idea" de la Inmaculada. Pertenecía a la Hermandad de Nazarenos de Santa Cruz en Jerusalem de Sevilla, que había organizado aquella magna procesión cuando Roma permitió el piadoso culto a la Inmaculada en 1617, y a esta Hermandad dedicó su folleto Apacible conversación entre un tomista y un congregado acerca del misterio de la Purisima Concepción. Además era Alcalde veedor del gremio de pintores y Censor de la Inquisición en materia de pinturas sagradas.44 Por lo tanto, un gran personaje y el pintor más influyente de la sociedad sevillana de su tiempo.

Si invertimos la perspectiva y nos dirigimos al polo opuesto de la pintura religiosa, es decir, a la pintura mitológica y al desnudo, quizá podamos contemplar más cabalmente, con más exactitud, cuál era la auténtica postura de Pacheco. La carencia de pintura mitológica en Sevilla en la segunda mitad del siglo xvi está relacionada directamente con el problema del desnudo. En esta cuestión, como en tantas otras de aquel momento, la personalidad decisiva de Pacheco debió jugar un papel determinante. Que nuestro pintor conocía la pintura mitológica y era un degustador del desnudo queda probado por su testamento en el que otorga una lámina grande de "una Venus, guarne-

42 R. Pike, Aristocrats and Traders; Sevillian Society in the Sixteenth Century, Ythaca, 1972; sobre la situación social del artista vid. J "Gállego, El pintor de artesano a artista, Granada, 1976.

43 J. Gállego, Visión y simbolos en la pintura española del Siglo de Oro, Madrid, 1972, p. 9. Sobre Francisco Pacheco vid. J. M. Asensio, Pacheco y sus obras artisticas y literarias, Sevilla, 1886; H. Cook, "Pacheco, the Master of Velazquez", The Bur. lington Magazine, XII, 1907, Pp. 229-300; F. Rodriguez Marín, Francisco Pacheco, maestro de Veldazquez, Madrid, MCMXXIII; C. Salazar, "El testamento de Francisco Pacheco", Archivo Español de Arte y Arqueologia, IV, 1928, p. 155; A. Sancho Corbacho, "Francisco Pacheco, tratadista de arte", Archivo Hispalense, XXII, pp 111-146; P. Muller, "Francisco Pacheco as a Painter", Marsyas 19, 1961, pp. 34-44, M. Barbadillo, Pacheco, su tierra y su tiempo, Jerez, 1963; Jonathan Brown, Images and Ideas in Seventeenth Century Spanish Painting, Princeton, 1978.

$44 \mathrm{~F}$. Pacheco, op. cit., pp. xxxvir y xu.r. 
cida de peral" a su amigo el Inquisidor del tribunal del Santo Oficio, don Francisco de Rioja. ${ }^{45}$ Sin embargo, su posición social y gremial de Alcalde veedor y Censor de la Inquisición le impedían permitir este género de pinturas, lo cual no era óbice para que aquella Venus pasara a manos de otro personaje del tribunal del Santo Oficio de la Inquisición, el cronista y bibliotecario de Su Majestad, don Francisco de Rioja. Esto nos corrobora que el desnudo, aunque admirado en abstracto, era considerado siempre como algo peligroso, por lo que las escasas representaciones existentes de este género, cuando era necesario, pasaban a manos de absoluta confianza como las de los Inquisidores del Santo Oficio. Por consiguiente, podemos considerax la postura de Pacheco como un tanto hipócrita, pues, aun cuando apreciaba el desnudo en general, trataba de guardar el "recato" como postura "oficial".46

Esta postura se trasluce también en su Apacible conversación entre un tomista y un congregado acerca del misterio de la Purisima Concepción, cuando el tomista nos dice:

"¿Quién pondrá puertas al campo? eso hace el vulgo con pasión, como ha hecho otras demasías contra los religiosos de una orden tan grave como la de Santo Domingo, y que tanto provecho ha traído a la Iglesia". ${ }^{47}$

A través de estas palabras del tomista, Pacheco parece reconocer la injusticia de las tropelías cometidas contra los dominicos que siempre se han destacado por su celoso servicio a la Iglesia. Por otro lado, admite que el apasionamiento del pueblo se aparta de la razón y cada vez se hace más difícil que las aguas vuelvan a su cauce. El vulgo actúa con pasión, irracionalmente. Sin embargo, Pacheco va a crear el tipo de imagen ideal tanto para el exquisito grupo de aristócratas de su cenáculo como para ese vulgo irracional que creerá fervorosamente en esa imagen por los siglos de los siglos, incluso después de aprobado el dogma por Roma. En este sentido, como decíamos anteriormente, su pintura participa de los caracteres de un arte elitista como es el ma-

$4 \check{s}$ C. Salazar, $o p$. cit", p. 159: "Item quiero y es mi boluntad que una lámina gran. de que yo tengo de una benus, guarnecida de peral se dé al $\mathrm{Sr}_{\text {. don Franco de }}$ rrioxa Ynq-r del tribunal del $\mathrm{St}^{\circ} \mathrm{Of}^{\circ}$ de esta ciudad y cronista y bibliotecario de su mag-d o se de a la persona que hordenare'.

46 V. Lleó, Nueva Roma: Mitología y humanismo en el Renacimiento sevillano, Sevilla, 1979, pp. 205-206.

47 J. M. Asensio, op. cit., p. 290. 
nierismo y de los caracteres de un arte de gran audiencia popular como es el barroco, pues no olvidemos que el cuadro de la Inmaculada y Miguel Cid permanecía en 1687 en la nave del Lagarto de la Catedral de Sevilla, junto al púlpito que servía para predicar el sermón todos los domingos del año. No sabemos con certeza cuándo sería trasladado a su actual emplazamiento en la Sacristía de los Cálices, pero cabe pensar que en la segunda mitad del siglo xvin, cuando se realizan obras en dicha nave y ya había sido aceptado aunque no aprobado el dogma. En ese momento ya habían triunfado las Inmaculadas de Murillo, y la escuela sevillana del siglo xvil copiaba hasta la saciedad el estilo y la iconografía murillesca. ${ }^{48}$

Sólo desde esta vertiente de un arte de gran audiencia popular podemos comprender las palabras de Menéndez y Pelayo cuando, al des. tacar la estética idealista de Pacheco, afirma que el famoso tratadista consideraba la pintura únicamente como una manera de oratoria "que se encamina a persuadir al pueblo... y llévalo a abrazar alguna cosa conveniente a la religión", como decía el propio Pacheco. ${ }^{49}$

Pacheco no hace más que mantenerse fiel al espíritu de la Contra. rreforma y a las directrices del Concilio de Trento respecto a sagradas imágenes. Crea una imagen aceptable por la élite de sus amigos los aristócratas sevillanos, pero también una imagen capaz de persuadir al pueblo. Sólo grandes pintores como Zurbarán o Murillo poseen e] talento de crear tipos ideales dotándolos de una atractiva personalidad. No es éste el caso de Pacheco. En su pintura fría, seca, sin movimiento, vemos sólo el mérito de haber creado un tipo iconográfico que alcanzará larga vida en la escuela sevillana. Al igual que en Juan de Juanes, ${ }^{50}$ la labor de Pacheco consiste en imponer una idea visual de lo que él cree que se debe entender por piedad, estableciendo un repertorio de imágenes frente a las cuales el pueblo pueda rezar por los siglos de los siglos.

De esta manera la imagen se nos presenta como algo "instituido", que es digno de ser conservado, que se conserva y que actúa en el tiempo. Es decir, se establece en la obra de arte un carácter institucional

48 D. Angulo, Murillo, Madrid, 1981; J Guerrero Lovillo, "La pintura sevillana del siglo xuIr", Archivo Hispalense, 1955, passim.

49 M. Menéndez Pelayo, Historia de las ideas estéticas en España, Santander, 1940, pp. 415.416.

50 D. C. Bayon, "Figuración y temática. La piedad popular en el manierismo español", Revista de Occidente, 64, 1968, pp. 32-51. 
con todas sus consecuencias. ${ }^{51}$ El mecenas, el tratadista, el artista han fundado algo. Han fundado un símbolo. Símbolo que tendrá vigen. cia e ingresará en el tiempo. Angulo ha destacado el valor puramente histórico de esta Inmaculada.$^{\mathbf{5}}$ Lo histórico se transforma en estético cuando representa un símbolo digno de ser conservado. El cuadro dependía del significado a fin de poder convertirse en centro de la meditación y testimonio del poder. Como diría Gombrich, "sin esta primacía absoluta del significado no se hubiera llegado nunca a la apreciación de la forma".53

De todo lo anteriormente expuesto podemos extraer las siguientes conclusiones: $1^{\text {a }}$, coincidiendo precisamente con el inicio de la crisis de la monarquía hispánica comenzó una etapa de gran efervescencia religiosa en toda España, cuya más estrepitosa manifestación fue la disputa que tuvo lugar en Sevilla acerca del dogma de la Inmaculada Concepción de María, en la cual tuvo destacado interés la aristocracia hispalense como demuestra la serie de cuadros de la Inmaculada con retrato del donante pintada por Pacheco, de la que el que hemos analizado forma parte; $2^{3}$, al revivir viejas creencias medievales con el objeto de convertirlas en dogma, intentando demostrar la antigüedad del cristianismo en la Península Ibérica, la Iglesia española no sólo se atenía a los preceptos del Concilio de Trento sino que también expresaba su preeminencia de "catolicidad" sobre la de los demás países europeos; 3a , Pacheco, influyente pintor y reconocido tratadista de arte, censor de la Inquisición, será la persona encargada de "instituir" el modelo iconográfico capaz de "persuadir" al pueblo y del que derivarán las representaciones de la Inmaculada realizadas por los pintores de la escuela sevillana.

\section{NOTA POST-SCRIPTUM}

Después de redactado este artículo ha aparecido en México el libro del profesor Santiago Sebastián, Contrarreforma y barroco, Madrid, 1981, que trata también el tema de la Inmaculada Concepción (pp. 222-228).

51 M. Rassem, Gesellschaft und bildene Kunst. Eine Studie zur Wiedersherstel. lung des Problems, Berlin, 1960, p、64 apud H. Bauer, Historiografia del arte, Madrid, 1980, p. 179.

52 D. Angulo, Pintura del siglo xviI, "Ars Hispaniae", XV, p. 323.

53 E. H. Gombrich, Freud y la psicologia del arte Estilo, forma y estructura a la luz del psicoanálisis, Barcelona, 1971, p. 58. 